\title{
Analysis of Cost Structure of China's Passenger Cars Manufacturing Industries
}

\author{
Kun Liu \\ School of Economics and Management \\ Fuzhou University \\ Fuzhou, China
}

\begin{abstract}
The manufacturing capacity of passenger cars represents one country's overall manufacturing ability. Recently, passenger cars manufacturing industries (PCMI) of China were faced with some challenges including rising production costs, declining productivity, and unreasonable cost structure. In this article we analyzed the cost structure of 12 Chinese listed passenger cars manufacturers and compared them with those of Ford Motor, Toyota Motor, and Volkswagen Motor, the most representative passenger cars manufacturers from the United States, Japan and Germany. The results indicated that there existed much potential for reducing the materials costs, taxes costs, and financing costs in the cost structure of China's PCMI. At the same time the investments in research and development should be enhanced further, which would be generally low at present. And we found that the rising labor costs were not the main reason in profit decline of China's PCMI.
\end{abstract}

Keywords-passenger cars manufacturing industries; cost structure; research and development investments

\section{INTRODUCTION}

As China gradually steps into the post-industrialization era, its economic growth is slowing down and the demographic dividend is disappearing, the production costs are rising, return on capital is declining, and the risk of hollowing of the real economy is increasing. The real economy demonstrates a country's overall economic abilities, and hence its decline in profitability will severely impact the development of China's economy. Accordingly, the urgent tasks for China's manufacturers are optimizing the distribution of the manufacturing supplies, lowering the costs of manufacturing, and strengthening innovation capacity. Passenger cars manufacturing industries (PCMI) require intensive capital and technological investments, which are why their manufacturing capacity is the representative of a country's national manufacturing abilities. According to financial reports of 12 listed companies 1 , the total revenue scale of these companies expanded from 56.96 billion yuan in 2010 to 121.46 billion yuan in 2016, while the profit margin was declining annually. Excluding the extraordinary gains and losses, income margin

12 listed companies from Shenyin Wanguo Securities industry sector classification, including SAIC (600104), BYD (002594), Guangzhou Automobile Group (601238), Great Wall Motor (601633), Changan Automobile (000625), JAC (600418), FAW Car (000800), Dongfeng Motor (600006), FAW Xiali (000927), Lifan shares (601777), hippocampus car (000572), Jinbei Automobile (600609) decreased from $13.82 \%$ in 2010 to $-9.42 \%$ with 6 companies operating at a very low profits or at a loss in 2016. As China began to lose its advantage of labor costs, the costs of materials, energy, financing and taxes were rising, and the China's PCMI were losing their competitiveness; at the same time, when it came to technological innovation, China's PCMI, as late starters in technological development, were found that it was increasingly difficult to learn new advanced technologies as it was heading towards the cutting-edge technology. Furthermore, because of the inadequate investments in $R \& D$, the independent innovation of China did not reach a decent scale yet, and the production efficiency was declining. Therefore, China's PCMI were facing the problem of rising costs and insufficient investments in R\&D.

As the integration degree of information technology and cars manufacturing was enhancing, the international competition in the PCMI would become more intense. While the China's industries lowered production costs, they should optimize the structure of production cost more reasonably, increase investments in $R \& D$ to make independent innovation exclusive to increase production efficiency and realize industry structure upgrade. In this article, we would begin the analysis from the cost structure of the China's PCMI, then we would find the main causes behind the rise in production costs on the one hand, and on the other hand, we would analyze the reasonability of the cost structure of the China's PCMI, which would help explore the underlying problems in the cost structure of the China's passenger cars manufacturing, and would provide the theoretical basis for the increasing of international competitiveness sustainable development of the China's PCMI and realizing structural reform of the supply side of the industry.

\section{ANALYSIS OF COST STRUCTURE OF CHINA'S PCMI}

In recent years, there has been a rapid rise in the labor costs of China's manufacturing industries, and the gap between China's labor costs and those in developed countries is narrowing, while it has surpassed those in some of the Southeast Asian countries. Energy and land costs are still lower than Japan, South Korea and other resource-scarce countries, however, they are still much higher than those in the United States and some Southeast Asian countries. Although the overall taxes costs are lower than the OECD countries, they are higher than the United States, Japan, South Korea, Brazil, India 
and other major industrial countries; financing costs continue to maintain a higher level than the United States, Japan, Britain and other major developed countries 2 . In order to enhance the competitiveness of manufacturers, boost the transformation and upgrading of manufacturing, and implement the structural reform on the supply side, we should firstly consider how to adopt some targeted and systematic measures to reduce the costs of manufacturing effectively and assist the manufacturers. In this article, we would conduct analysis on passenger cars manufacturers which were capital-intensive and technologyintensive manufacturers, then to explore the factors contributing to the rise of industry manufacturing costs.

\section{A. Analysis of Profit of China's PCMI}

Passenger cars refer to cars with 9 or less seats, of which the manufacturing process integrates advanced technology, accurate industrial chain management, and intricate industrial process. Therefore, the manufacturing level of passenger cars is a benchmark for a country's manufacturing industries, and the action program of "Made in China 2025" and "German industry 4.0", attached great importance to the PCMI. China's PCMI, as late starters, they took a series of measurements in early 21 st century to introducing advanced technologies including setting up joint ventures with companies from developed countries and taking over the shares of companies specializing in high-tech from developed countries. Then China's PCMI could learn not only the advanced technologies and techniques but also the advanced management systems and experiences from developed countries. Due to the technology spillover effect, China's PCMI have made rapid progress. China had a total of 21 local brands of passenger cars manufacturers, including 12 listed companies, 32 independent brands, resulting in a total sale of 10.5286 million in 2016, which is 8 times that of 1.38 million in 2008. However, with the Chinese economy entering into the "new normal", economic growth was slowing down, manufacturing costs began to rise, it became increasingly difficult for China's PCMI to learn from developed countries, while the abilities of independent technological innovation of China were not yet mature, which would led to the profit decline of China's PCMI.

From "Fig. 1", it can be seen that the 12 listed companies all had declining profit in 2010, income margin (excluding the extraordinary gains or losses) fell into the negatives for the first time in 2013 and the declining trend became apparent from then, indicating that the costs of China's PCMI were gradually rising. It can be concluded that PCMI were a typically capitalintensive and technology-intensive industries, and at the same time, it was also a labor-intensive industry, which made the cost structure more complex. Hence we would start to analyze the financial statements to figure out the changes of the following accounts: operating costs, cost of sales, administrative expenses and finance costs.

From "Fig. 2", It could be seen that the overall costs of China's PCMI were on a gradual rise, with operating costs that mainly consist of manufacturing costs in 2016 had reached $88.3 \%$ of the revenue, which seriously squeezed the gross

China margin of sales. In addition, cost of sales, administrative expenses and finance costs had significantly increased after 2013 , indicating that the rise in costs became one major factor in hindering PCMI from becoming competitive.

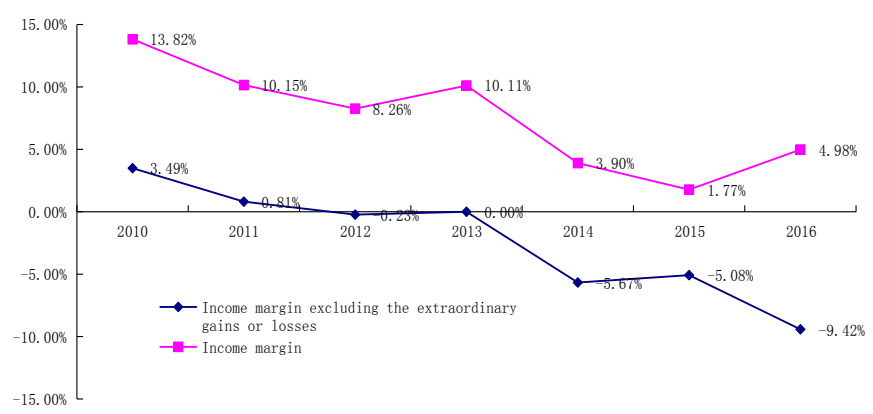

Fig. 1. Income margin of China's PCMI (2010-2016).
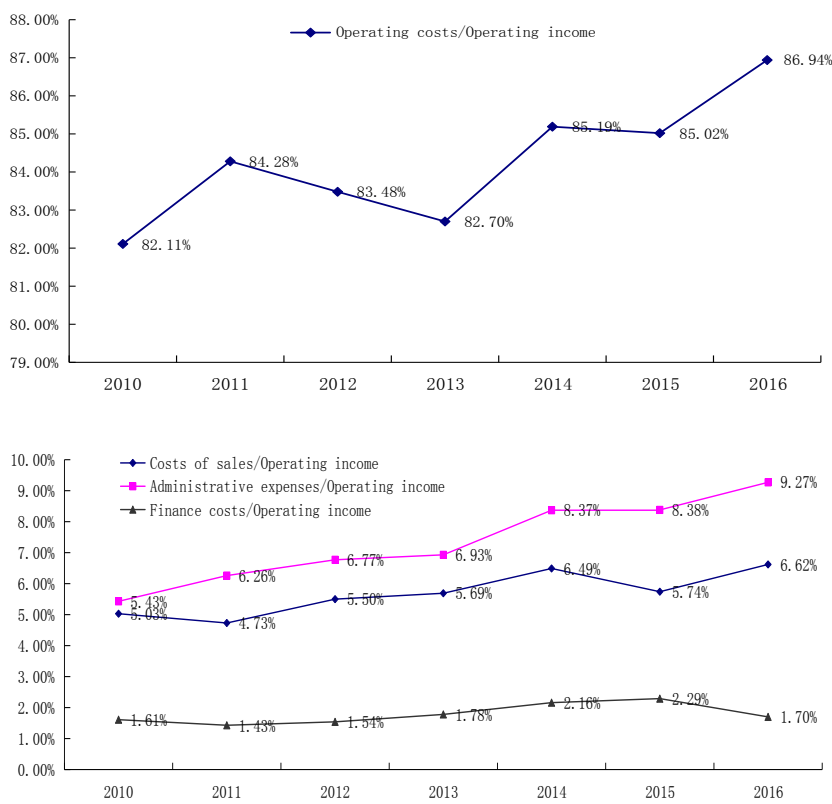

Fig. 2. Changes of costs items of China's PCMI (2010-2016).

\section{B. Analysis of Cost Structure of China's PCMI}

To further explore the elements attributed to costs increase, this article fractionized the cost structure of China's PCMI by different cost functions. This analysis would base on the actual characteristics of China's PCMI, and the cost items could be categorized into 7 types including labor costs, materials costs, R\&D investments, taxes costs, financing costs, logistics costs and advertising costs. Statistics had been gathered from the 12 passenger cars companies' annual reports (2010-2016). According to the rules of the preparation of China's financial statements, labor costs included salaries and welfare which shown in "Cost of manufacture", "Administrative Expenses", "Cost of Sales". Since the record of such information in the income statements and in the notes on the financial reports was incomplete, we used the approximate numbers shown in "cash paid for employees" of cash flow statements in this article. To 
reflect the taxes costs comprehensively, the analysis not only included the income tax, consumption tax, stamp duty and other income taxes but also included added-value tax which did not affect revenue of enterprises, and in this article we used the approximate numbers shown in "taxes paid" of cash flow statements. In this analysis, in order to fully reflect the capital costs including debt and equity, we used the approximate numbers shown in cash flow statement, and the items would include the total amount of "payment of interest, fees and commission of cash" in the operating activity of the flow chart and the total amount of "dividends for distribution of dividends, profits or interest payments" in the financing activities. Logistics costs were derived from the cost of sales including transport, storage and packaging costs. Advertising costs were derived from the cost of sales including advertising fees and promotion fees. R\&D investments were the key factor in PCMI.
According to China's financial statements, the R\&D investments, which affected the gains and losses of the current period, included parts of the expenses of the research stage and the costs that failed to convert to be the intangible assets. However, in order to investigate the $R \& D$ investments as a whole, the capitalized R\&D investments were also included in the statistical scope. Raw materials expenses, semi-finished product procurement and fuel power as well as other cost items, made up the largest proportion of the costs of PCMI, and the changes of these costs would play a decisive role in the changes of the whole costs. The analysis would use the numbers approximately shown in the enterprise's financial statements, constituting by the main operating costs excluding labor costs and the costs of depreciation and amortization. Finally, for the 12 listed companies of PCMI from 2010 to 2016, the cost-to-income ratios were computed as in "Table I":

TABLE I. COST-TO-INCOME RATIOS OF CHINA'S PCMI (2010-2016)

\begin{tabular}{|c|c|c|r|r|r|r|r|}
\hline Years & $\begin{array}{c}\text { Labor } \\
\text { costs }\end{array}$ & $\begin{array}{c}\text { Taxes } \\
\text { costs }\end{array}$ & $\begin{array}{c}\text { Financing } \\
\text { costs }\end{array}$ & $\begin{array}{c}\text { Logistics } \\
\text { costs }\end{array}$ & $\begin{array}{c}\text { Advertising } \\
\text { costs }\end{array}$ & $\begin{array}{c}\text { R\&D } \\
\text { investments }\end{array}$ & $\begin{array}{c}\text { Materials } \\
\text { costs }\end{array}$ \\
\hline 2010 & $4.48 \%$ & $7.83 \%$ & $2.10 \%$ & $1.85 \%$ & $1.60 \%$ & $1.97 \%$ & $75.83 \%$ \\
\hline 2011 & $4.39 \%$ & $7.44 \%$ & $2.63 \%$ & $1.68 \%$ & $1.43 \%$ & $2.35 \%$ & $77.17 \%$ \\
\hline 2012 & $4.70 \%$ & $6.26 \%$ & $2.98 \%$ & $1.74 \%$ & $1.42 \%$ & $2.28 \%$ & $78.14 \%$ \\
\hline 2013 & $4.45 \%$ & $5.29 \%$ & $2.31 \%$ & $1.70 \%$ & $1.38 \%$ & $1.92 \%$ & $80.27 \%$ \\
\hline 2014 & $4.68 \%$ & $4.79 \%$ & $3.24 \%$ & $1.73 \%$ & $1.53 \%$ & $2.23 \%$ & $80.19 \%$ \\
\hline 2015 & $5.10 \%$ & $4.60 \%$ & $3.44 \%$ & $1.54 \%$ & $1.35 \%$ & $2.28 \%$ & $80.00 \%$ \\
\hline 2016 & $5.53 \%$ & $5.17 \%$ & $3.19 \%$ & $1.66 \%$ & $1.37 \%$ & $2.30 \%$ & $78.55 \%$ \\
\hline
\end{tabular}

From the above "Table I", it indicated that costs of China's PCMI which weight by their income were rising year by year, and the table showed that profit from manufacturing industries was gradually disappearing, which was not conducive to PCMI. Taxes costs were declining from 2010 to 2015, indicating that the government of China was constant supporting the industry of auto manufacturing through tax policies, such as absorbing PCMI into scope of high-tech enterprises for more tax incentives. In 2016, taxes costs increased, which were relevant to the proportion of consumption tax adjustment. With the full implementation of transformation from business tax to valueadded tax, the tax burden of China's PCMI would be further reduced. Financing costs were on the rising trend as a whole, mainly because the debt interest rate was rising, which had brought the pressure on the manufacturers to a certain extent. Logistics costs and advertising costs as a whole had been shown as a declining trend, indicating that China's passenger cars manufacturers had compressed the cost of sales effectively. R\&D investments as a whole had a steady growth trend, with proposing of the concepts of "Internet +" and "New Energy", the integration degree of PCMI and internet industries or new energy industries was promoted, And so, "Electrification, Networking, Intelligence, and Resource-sharing" were proposed as the key developmental goals of PCMI, representing the development direction of the industries. It would require passenger car manufacturers to promote the R\&D investments continuously, and to support the development of original innovations especially. Materials costs used in the passenger cars manufacturers had been shown as an increasing trend in recent years, mainly because the steel and other raw materials prices as well as the prices of engine and other core components of passenger cars were on the rise trend. So the rise in the cost of materials narrowed the profit margins of PCMI constantly in recent years.

\section{Analysis of Contribution of Each Type of Costs to Total Costs}

In view of the cost structure constituted by the 7 types of costs mentioned above, we intended to further analyze the contribution ratios of the changes of each type of costs to changes of total costs. We first did logarithm of the growth rate of the total costs of the 12 listed companies, and then used normalization method to rebuild the logarithm. And next step, we did logarithm of the growth rate of each specific type of costs, and used the same normalization method to rebuild the logarithm. Finally, we processed variance decomposition using the logarithm acquired above. Based on these processed data, the following conclusions could be drawn in "Table II':

TABle II. CONTRibution Ratios of The Changes of EACH Type of Costs to Changes of Total Costs (2010-2016)

\begin{tabular}{|c|c|c|c|c|c|c|c|}
\hline Items & $\begin{array}{c}\text { Labor } \\
\text { costs }\end{array}$ & $\begin{array}{c}\text { Taxes } \\
\text { costs }\end{array}$ & $\begin{array}{c}\text { Financing } \\
\text { costs }\end{array}$ & $\begin{array}{c}\text { Logistics } \\
\text { costs }\end{array}$ & $\begin{array}{c}\text { Advertising } \\
\text { costs }\end{array}$ & $\begin{array}{c}\text { R\&D } \\
\text { investments }\end{array}$ & $\begin{array}{c}\text { Materia } \\
\text { 1s costs }\end{array}$ \\
\hline $\begin{array}{c}\text { Variance } \\
\text { decomposition }\end{array}$ & $16.79 \%$ & $55.75 \%$ & $12.76 \%$ & $32.35 \%$ & $29.96 \%$ & $55.85 \%$ & $96.65 \%$ \\
\hline
\end{tabular}


The findings acquired from "Table II" can be concluded below: firstly, changes in materials costs made the largest contribution to the total costs changes, so materials costs control should be a focus of passenger cars manufacturers; secondly, R\&D investments made the second contribution to the total costs changes, and R\&D investments had created large changes to the total costs, it affected the innovation ability of manufacturing enterprises, which was the driving force for sustainable development of enterprises, so $R \& D$ investments should be supported by the companies constantly; thirdly, taxes costs made the third contribution to the total costs changes, so promoting of taxes incentives would reduce the further costs burden of passenger cars manufacturers; fourthly, logistics costs and advertising costs included in "Cost of Sales" made the fourth contribution to the total costs changes, so passenger cars companies should enhance their own sales management capacity to reduce the effect of cost of sales on profit margins; fifthly, labor costs and the financing costs made the weak contribution to the total costs changes relatively, therefore, the influence of labor costs and financing costs on the increase of total operating costs of passenger cars companies in recent years was limited.

\section{COMPARISON IN MANUFACTURING COSTS BETWEEN} CHINESE AND INTERNATIONAL PASSENGER CARS PRODUCTION

For the analysis of passenger cars manufacturing enterprises, we selected Ford Motor, Toyota Motor, Volkswagen Motor, which represented the production level of PCMI from the United States, Japan and Germany to compare with Chinese PCMI. The comparative analysis would use the data collected through the same caliber and the same calculation mothed above, cost-to-income ratios were shown as follow:

TABLE III. COST-TO-INCOME RATIOS EACH TYPE OF COSTS IN FORD MOTOR (2010-2016)

\begin{tabular}{|c|c|c|c|c|c|c|}
\hline Years & Labor costs & Taxes costs & $\begin{array}{c}\text { Financing } \\
\text { costs }\end{array}$ & $\begin{array}{c}\text { Advertising } \\
\text { costs }\end{array}$ & $\begin{array}{c}\text { R\&D } \\
\text { investments }\end{array}$ & $\begin{array}{c}\text { Materials } \\
\text { costs }\end{array}$ \\
\hline 2010 & $12.42 \%$ & $0.46 \%$ & $1.40 \%$ & $3.02 \%$ & $3.88 \%$ & $66.95 \%$ \\
\hline 2011 & $11.76 \%$ & $0.00 \%$ & $0.60 \%$ & $3.01 \%$ & $3.89 \%$ & $65.05 \%$ \\
\hline 2012 & $12.56 \%$ & $1.53 \%$ & $1.10 \%$ & $2.98 \%$ & $4.10 \%$ & $66.69 \%$ \\
\hline 2013 & $12.16 \%$ & $0.00 \%$ & $1.64 \%$ & $2.99 \%$ & $4.22 \%$ & $61.35 \%$ \\
\hline 2014 & $12.86 \%$ & $0.80 \%$ & $1.91 \%$ & $2.98 \%$ & $4.65 \%$ & $62.00 \%$ \\
\hline 2015 & $13.14 \%$ & $1.93 \%$ & $2.11 \%$ & $2.88 \%$ & $4.48 \%$ & $62.21 \%$ \\
\hline 2016 & $13.12 \%$ & $1.44 \%$ & $2.81 \%$ & $2.83 \%$ & $4.81 \%$ & $61.42 \%$ \\
\hline
\end{tabular}

TABLE IV. COST-TO-INCOME RATIOS EACH TYPE OF COSTS IN TOYOTA MOTOR (2010-2016)

\begin{tabular}{|c|c|c|c|c|c|c|}
\hline Years & Labor costs & Tazes costs & $\begin{array}{c}\text { Financing } \\
\text { costs }\end{array}$ & $\begin{array}{c}\text { Advertising } \\
\text { costs }\end{array}$ & $\begin{array}{c}\text { R\&D } \\
\text { investnents }\end{array}$ & $\begin{array}{c}\text { Materials } \\
\text { costs }\end{array}$ \\
\hline 2010.3 & $10.56 \%$ & $0.54 \%$ & $1.20 \%$ & $1.77 \%$ & $4.22 \%$ & $73.51 \%$ \\
\hline 2011.3 & $10.50 \%$ & $1.81 \%$ & $0.98 \%$ & $1.78 \%$ & $4.22 \%$ & $76.28 \%$ \\
\hline 2012.3 & $11.29 \%$ & $1.54 \%$ & $1.06 \%$ & $1.79 \%$ & $4.59 \%$ & $78.64 \%$ \\
\hline 2013.3 & $9.74 \%$ & $2.70 \%$ & $1.04 \%$ & $1.62 \%$ & $3.95 \%$ & $77.01 \%$ \\
\hline 2014.3 & $8.79 \%$ & $3.23 \%$ & $1.75 \%$ & $1.76 \%$ & $3.83 \%$ & $66.62 \%$ \\
\hline 2015.3 & $8.74 \%$ & $3.57 \%$ & $2.31 \%$ & $1.74 \%$ & $4.01 \%$ & $64.34 \%$ \\
\hline 2016.3 & $8.85 \%$ & $3.38 \%$ & $2.85 \%$ & $1.88 \%$ & $4.06 \%$ & $63.80 \%$ \\
\hline
\end{tabular}

TABLE V. COST-TO-INCOME RATIOS EACH TYPE OF COSTS IN VOLKSWAGEN MOTOR (2010-2016)

\begin{tabular}{|c|c|c|c|c|c|c|}
\hline Years & Labor costs & Taxes costs & $\begin{array}{c}\text { Financing } \\
\text { costs }\end{array}$ & $\begin{array}{c}\text { Advertising } \\
\text { costs }\end{array}$ & $\begin{array}{c}\text { R\&D } \\
\text { investnents }\end{array}$ & $\begin{array}{c}\text { Materials } \\
\text { costs }\end{array}$ \\
\hline 2010 & $15.00 \%$ & $2.45 \%$ & $1.72 \%$ & $1.01 \%$ & $5.55 \%$ & $70.38 \%$ \\
\hline 2011 & $14.97 \%$ & $2.84 \%$ & $1.60 \%$ & $0.97 \%$ & $5.07 \%$ & $73.65 \%$ \\
\hline 2012 & $15.31 \%$ & $2.24 \%$ & $1.58 \%$ & $1.04 \%$ & $5.51 \%$ & $70.85 \%$ \\
\hline 2013 & $16.11 \%$ & $1.96 \%$ & $1.72 \%$ & $1.06 \%$ & $6.71 \%$ & $72.62 \%$ \\
\hline 2014 & $16.71 \%$ & $1.89 \%$ & $1.85 \%$ & $1.08 \%$ & $7.39 \%$ & $74.64 \%$ \\
\hline 2015 & $17.00 \%$ & $1.42 \%$ & $0.64 \%$ & $1.28 \%$ & $7.40 \%$ & $78.13 \%$ \\
\hline 2016 & $17.04 \%$ & $1.60 \%$ & $1.09 \%$ & $1.22 \%$ & $7.35 \%$ & $75.43 \%$ \\
\hline
\end{tabular}

From "Table III-V", we found: (i) Labor costs: Labor costs of China's $\mathrm{P}$ were relatively low, and still had growth potentialities. While Ford and Volkswagen with their main production base in Europe and the United States, were bearing higher and rising labor costs. Toyota's production base was being transferred to regions such as Thailand and Indonesia, so their labor costs were declining. If China's labor costs continued to rise, it would reach to the same level of that of Toyota. (ii) Taxes costs: we found that the taxes burden of China's PCMI was heavier than the other three passenger cars manufacturers by 2-3 percentage points on average, indicating that there was still much room for improvement in tax support 
for China's PCMI. (iii) Financing costs: financing costs in China were slightly higher than those of three major passenger cars manufacturers. Further analysis would show that China's financing costs was mainly composed by the load interest expenses. However, the financing costs of the three passenger cars manufacturers was mainly composed by the dividend payable. The phenomenon indicated that the cost of debt capital was higher in China, so therefore there was potential for further decline. (iv) Advertising costs: the advertising costs of China's PCMI were almost the same as those of the three major groups. (v) R\&D investments: China's PCMI had increased the R\&D investments constantly in recent years, and the amount of these investments was still rising, however, they still fell behind that three passenger cars manufacturers by 2-5 percentage points, especially Volkswagen Motor, which was influenced by the "German industry 4.0" profoundly, had further promoted the R\&D investments since 2013. By comparison, the investments of China's passenger cars manufacturers in $R \& D$ were relatively insufficient, so if China's passenger cars manufacturers wanted to narrow the gap between them and the world's leading automakers, they would promote their $\mathrm{R} \& \mathrm{D}$ investments to realize independent innovation instead of imitation. (vi) Materials costs: we found that China's passenger cars manufacturers bore higher costs of the raw materials and the core components, however the three passenger cars manufacturers had less burden from the materials costs, mainly because of the capacity to produce the core components independently. So China's cars manufacturers should build up the capacity to produce the core components independently to get rid of dependence on import of core components as soon as possible.

\section{CONCLUSION}

This article chose the passengers cars manufacturing industries, which could represent the level of modern manufacturing industries development, to analyze the efficiency of China's cars manufacturing industries. Through the analysis of the cost structure of 12 listed companies from 2010 to 2016, we found that the annual increase of materials costs, labor costs, financing costs, $\mathrm{R} \& \mathrm{D}$ investments were hindering the profit realization. Advertising costs and logistics costs as well as other cost of sales were already effectively controlled by the companies, and taxes costs were declining to some extent. Through the further analysis based on the method of variance decomposition of the costs growth rate, we found that the materials costs, $R \& D$ investments and taxes costs would have large influence on the total costs, indicating that costs of China's PCMI were mainly incurred by materials costs and R\&D investments; while the increase in labor costs and financing costs had a relatively weak impact on the overall costs increase. This article further compared 12 Chinese listed companies with Ford, Toyota and Volkswagen, the world's leading manufacturers of passenger cars. Then we acuqired the findings within China's PCMI as follow: (i) labor costs still had growth potentialities; (ii) there still existed potentialities for reducing taxes costs and financing costs; (iii) R\&D investments needed to be further promoted; (iv) materials costs needed to continute to be controlled critically.

\section{ACKNOWLEDGMENT}

This research was made possible thanks to the financial support from the special fund provided by Scientific research startup project of Fuzhou University (Grant No.GXRC201705510481).

\section{REFERENCES}

[1] C. T. Hsieh, and P. J. Klenow, "Misallocation and Manufacturing TFP in China and India," National Bureau of Economic Research, No.07-06, 2007.

[2] Z. Jian, "Market Distortion, Inter-enterprises' Resource Allocation and Productivity in Manufacturing Sector," China Industrial Economics, Vol.1, pp.58-68, 2011.

[3] G. Gong, and G. Hu, "Efficiency of Resource Allocation and Manufacturing Total Factor Productivity in China," Economic Research Journal, Vol.4, pp. 4-15+29, 2013.

[4] Y. Shao, X. Bu, \& T. Zhang, "Resource Missallocations and TFP of Chinese Industrial Enterprises-A Recalculation Based on Chinese Industrial Enterprises Database," China Industrial Economics, Vol.12, pp. 39-51, 2013.

[5] P. Li, and Y. Ji, "Policy Orientation Transformed, Factor Market Distortions and FDI Technology Spillover," Nankai Economics Studies, Vol.6, pp.125-137, 2014.

[6] E. J. Bartelsman, \& M. Doms, "Understanding Productivity: Lessons from Longitudinal Microdata," Journal of Economic Literature, Vol.38, no,3, pp.569-594, 2000.

[7] H. Nie, and R. Jia, "Productivity of Manufacturing Firms and Misallocation of Resources in China," The Journal of World Economy, Vol.7, pp.27-42, 2011

[8] P. Sun, S.Hang, and Q. Xu, "The Effect of Sectoral Agglomeration on Labor Productivity," The Journal of World Economy, Vol.3,pp.33-53, 2013.

[9] Y. Chen, and Z. Tang, "Technology Choice and Technical Progress of China' s Industries :1985 — 2003,". Economic Research Journal, Vol.9, pp.50-61, 2006.

[10] Z. Yao, "Productivity Growth and Factor Reallocation: China' s Empirical Study," Economic Research Journal, Vol.11, pp.130-143, 2009.

[11] D. Restuccia, and R. Rogerson, "Policy Distortions and Aggregate Productivity With Heterogeneous Establishments," Review of Economic Dynamics, Vol.11, no.4, pp.707-720, 2008.

[12] M. Yu, and H. Pan, "The Relationship between Politics, Institutional Environments and Private Enterprises' Access to Bank Loans," Management World, Vol.8, pp.9-21, 2008.

[13] W. Liu, and H. Zhang, "Structural Change and Technical Advance in China's Economic Growth," Economic Research Journal, Vol.11, pp.415, 2008.

[14] L. Zhou, Y. Zhao, and L. Li, "Resource Misallocation and Political Cycles," Journal of Financial Research, Vol.3, pp. 15-29, 2013.

[15] S. A. Aoki, "Simple Accounting Framework for the Effect of Resource Misallocation on Aggregate Productivity," Journal of the Japanese and International Economies, Vol.26, no.4, pp. 473-494, 2012. 